Nevşehir Bilim ve Teknoloji Dergisi TARGíd Özel Sayı 355-363 2016

DOI: 10.17100/nevbiltek.210988

URL: http://dx.doi.org/10.17100/nevbiltek.210988

\title{
Çemen (Trigonella foenum-graecum L.) Bitkisinin Kullanım Alanları ve Tıbbi Önemi
}

\author{
Zeynep Gökçe ${ }^{1 *}$, Lale Efe ${ }^{2}$ \\ ${ }^{1}$ Kahramanmaraş Sütçü İmam Üniversitesi, Fen Bilimleri Enstitüsü, Tarla Bitkileri Anabilim Dall,
} Kahramanmaraş

${ }^{2}$ Kahramanmaraş Sütçü İmam Üniversitesi, Ziraat Fakültesi, Tarla Bitkileri Bölümü, Kahramanmaraş

Öz

Çemen Fabales takımının, Fabaceae (Baklagiller) familyasının, Trigonella cinsinde yer almaktadır. Türkiye'de yaygın olarak Trigonella foenum graecum L. türü yetiştirilmektedir. Çemen bitkisinin vejetatif kısmı ve tohumları çeşitli amaçlar için kullanılmaktadır. Bitkinin yeşil aksamı, kuru otu ve tohumları yüksek yem verimi ve kalitesinden dolayı yem bitkisi olarak kullanılmaktadır. Tohumları öğütülerek gıdalara lezzet vermek ve gıdaları korumak için baharat olarak kullanılmaktadır. Bunlara ilaveten bitkinin tohumlarından elde edilen boya ve yağın çeşitli kozmetik ürünlerde kullanıldığı bilinmektedir. Çemen, ince saplı yapısı ve toprakta iyi çözünmesi nedeniyle iyi bir yeşil gübre bitkisidir. Bu özelliklerinin yanında, tıbbi ve aromatik bitkiler içerisinde önemli bir yere sahiptir. Öğütülmüş tohumunun toz halinde tüketilmesi ile insan sağllğı üzerinde kan şekerini ve kolestrolü düşürücü özelliği yapılan çalışmalarla kanıtlanmıştır. Çemen tohumunun tedavi edici özelliğinin, embriyosunda bulunan, steroidal yapılı bir saponin olan diosgeninden kaynaklandığı bilinmektedir. Diosgenin kortikosteroidlerin sentezi için değerli bir maddedir. Çemen bitkisinden halk hekimliğinde ise, sindirimi kolaylaştırıcı, süt artırıcı, balgam söktürücü, ateş düşürücü, boğaz ağrısı giderici, yara iyileştirici olarak faydalanılmaktadır.

Anahtar Kelimeler: Çemen, Trigonella foenum-graecum L, tıbbi özellikleri, kullanım alanları

\section{Uses and Medicinal İmportance of Fenugreek (Trigonella foenum-graecum L.) Crop}

\begin{abstract}
Fenugreek is a crop from Trigonella species included Family of Fabaceae, Ordo of Fabales. In Turkey Trigonella foenum graecum L. species has been widely cultivated. Vegetative parts and seeds of fenugreek plant has been used for a number of purposes. Green parts, fodder and seeds of the plant has been used as a forage crop due to higher forage yield and quality. Its grinded seeds has been used as a spice in order to make the food's taste delicuous and protect the foods. In addition to it is known that dye and oil obtained from seeds of the plant has been used in various cosmetic products. Fenugreek is a good green manure crop because of its fine stalk structure and well dissolution in the soil. Moreover fenugreek has an important place among medicinal and aromatic plants. Studies indicated that it has reducing effect of blood sugar and cholesterol for human health when it is consumed grinded seed as powder. It is known that curing effect of fenugreek seed results from diosgenin which is a saponin with steroidal structure and exists in embryo. Diosgenin is a valuable substance for synthesis of corticosteroids. In folk medicine fenugreek crop has been utilized as digestive, stimulating milk flow in breast-feeding, expectorant, antipiretic, sore throat reliever and healing wounds.
\end{abstract}

Keywords: Fenugreek, Trigonella foenum-graecum L, medicinal properties, uses

*e-mail: zeynep_gokce_@hotmail.com 


\section{Giriș}

İnsan yaşamında önemli bir yer tutan bitkilerden bazıları ilaç-baharat bitkileri olarak bilinmekte ve büyük çoğunluğu aynı zamanda aromatik özellikte olduğu ve tıbbi amaçlı kullanıldıkları için tıbbi ve aromatik bitkiler olarak da bilinmektedir [1].

Son 20-30 yılda gerek evsel, gerek endüstriyel çapta gıdalarda baharat kullanımı büyük artış göstermiş̧tir. Değişen ve gelişen beslenme alışkanlıkları, yöresel yemeklere ve ilginç damak zevklerine yöneliş, yeni gıda ürünlerinin ortaya çıkması ve bazı teknolojik gerekler, baharatlardan çeşitli formlarda ve alanlarda yararlanılmasını gündeme getirmiştir. Baharatın doğrudan kendisinin tüm ve öğütülmüş olarak gıdalara katılması hala önemini korumakla birlikte, çözünür ürünlerin elde edilmesi ve kullanılması birçok avantaj sağlamaktadır [2].

Türkiye, tıbbi ve aromatik bitkiler bakımından dünyanın en zengin ülkelerinden biridir. Dünyada yaygın olarak bulunan fesleğen, çemen, rezene, anason, haşhaş, kimyon, kişniş, safran, defne gibi önemli tıbbi aromatik bitkilerden hepsinin ülkemizde kültürü yapılmaktadır. Çemen bitkisi de bu bitkiler içerisinde önemli bir yere sahiptir [1].

Çemen, Eski Mısır'da yaklasık M.Ö. 2000 yıllarında tarıma alınmıştır. Eski Yunanlı bilginfilozoflardan Theophrastos (M.Ö. 372-287) ve Dioskurides (M.Ö. I. Yüzy1l) tarafindan çemen için inek boynuzu (Buceras) ve keçi boynuzu (Aegoceras) isimleri kullanılmıştır. Romalılar devrinde Plinius (M.S. 23-79) ve Columella (M.S. I. y.y.) da eski yunancadan gelme Buceras ve Aegoceras adlarını kullandıkları gibi, "Yunan kuru otu" (foenum graecum), hatta "slicia” veya "siliqua" diye de adlandırmışlardır. Çemen, Mısır'ın en eski kültür bitkisi olduğu gibi, Hint uygarlı̆ğ döneminde de tarımının yapıldığı ve adının Sanskritçe’de bulunduğu da tespit edilmiştir [3].

\section{2. Çemen Bitkisinin Genel Özellikleri}

\subsection{Taksonomisi}

Çemen Fabales takımının, Fabaceae (Baklagiller) familyasının, Trigonella cinsinde yer almaktadır. Halk arasında" buy otu" olarak bilinen bu bitki dünyada geniş yayılma alanına sahiptir.

Trigonella cinsi çoğunlukla Akdeniz çevresinde yayllış gösteren 50 kadar tür içermektedir ve bu türlerden de 45'i Türkiye' de doğal olarak yetiştirilmektedir. Türkiye'de bunlardan Trigonella foenumgraecum L. türünün kültürü yapılmaktadır [4, 5].

\subsection{Bitkisel özellikleri}

Türkiye şartlarına göre, 30-60 cm arasında boylanan bir yıllık ve otsu bir yapıda gelişen çemen bitkisinin, sapları yuvarlağa yakın ve içi boştur. İlk gelişme döneminde tüylü olup, daha sonra çıplak bir yapı göstermekte ve koyu yeşil renktedir. Yan dallar yaprak koltuklarından çıkmaktadır. Yapraklar yonca gibi üçlüdür, yaprak sap1 $5.3 \mathrm{~mm}$ uzunluğunda olup bitkide üst yapraklar biraz kalınca ve tüylüdür. Yaprakçıklar hemen hemen aynı irilikte, 10-40 mm uzunluğunda ve $8-15 \mathrm{~mm}$ genişliğinde ters yumurta formu gösterirler. Dipte ise daima kama formuna dönüşmektedirler. Orta yaprakçıklar uzun sapçıklı olup, yandaki yaprakçıklar sapsız bağlanmışlardır. Her üç yaprakçıkta da taban düz kenarlı, üst kısımlar ise dişlidir. Ancak yoncanın aksine orta damar uzantısı belirgin değildir. Kulakçık oldukça iri ve üçgenimsi, mızraksı bir formdan yumurta formuna kadar değişik șekiller göstermektedir. Çiçekler 10- 18 mm 
uzunluğunda tek veya ikili olarak yaprak koltuklarından çıkar ve sapsızdırlar. Taç yapraklar sarımsı beyaz, bazen hafif pembe renklidir. Taç yapraklar çanak yaprağa nazaran iki kat daha uzundur ve dişta bir bayrak, içte iki adet kanatçık ve kayıkçıktan meydana gelmiştir. Kanatçıklar bayrakçığın yarı uzunluğundadır. Kayıkçık küt veya yuvarlakça olup ancak çanak uzunluğundadır. Taç yapraklar tabanda altı parçalı çanak yaprakla sarılmıştır. Çanak yaprağın üzeri bariz tüylüdür. Baklalar 5- 11 cm uzunlukta kıvrık ve sivri uçlu olup, ortalama 10-20 adet arasında tohum taşır [3, 6].

Çemen tohumu, Trigonella foenum graecum L. (Leguminosae) türünün olgun tohumudur. Dış görünüş olarak 3-5 mm uzunlukta olup, sert köşeli, üzeri ince pürtüklü, esmer kırmızı veya sarımsı esmer renklidir. Ayrıca kokusuz ve hoş olmayan lezzetlidir. Tohumların ögütülmüş hali kuvvetli ve özel bir kokuya sahiptir [7]. Tohumun kendine özgü kokusu, 3-Hydroxy-4,5-Dimethyl-2(5H)-Furanon bileşiminden kaynaklanmaktadır [8].

\subsection{Yetiştiriciliği}

Çemen bitkisinin, dünyada Hindistan, Fas, Mısır, Cezayir, Türkiye, İtalya, İspanya, Fransa ve Yunanistan gibi ülkelerde tarımı yapılmakla beraber [2, 3], ülkemizde ise Konya, Kayseri, Çankırı, Ankara, Gaziantep, Kahramanmaraş, Afyon, Şanlıurfa ve Hatay gibi illerde yetiştiriciliği yapılmaktadır $[9,10]$

Çemen bitkisi, kurağa ve yüksek sıcaklığa dayanıklı bir bitkidir. Ayrıca 1lıman iklimlerde iyi gelişir ve kışlık olarak ekilebilmektedir. Ülkemizde sıcak bölgelerde, erken ilkbaharda veya kışlık olarak, soğuk bölgelerde ise yazlık olarak ekimi yapılmaktadır [11, 12].

Ülkemizde çemenin kültür türü yanında çok sayıda yabani türlerinin de bulunması sebebiyle bitkinin daha iyi tanınması sağlanarak yetiştiriciliğinin yaygınlaştırılması ve ülke yararına değerlendirilmesi gerekmektedir. Dolayısıyla, ülkemiz ekolojisinde çemen bitkisi toprak ve iklim istekleri açısından geniş sınırlara sahip olup hemen hemen buğdayın yetiştiği her yerde çemen yetiştiriciliğinin yapilabilmesi mümkündür [13].

Ülkemizde üretimi yapılan bazı baharat bitkilerinin ekim alanı (da), üretim (ton) ve verim değerleri (kg/da) Tablo 1.’de verilmiştir.

Tablo 1. Türkiye'de üretimi yapılan bazı baharat bitkilerinin ekim alanı, üretim ve verim değerleri*

\begin{tabular}{|c|c|c|c|c|}
\hline & YII & Ekim alanı (dekar) & Üretim (ton) & Verim (kg/da) \\
\hline \multirow{6}{*}{ KIRMIZI BİBER } & 2010 & 104.049 & 186.272 & 1790 \\
\hline & 2011 & 91.557 & 162.125 & 1771 \\
\hline & 2012 & 112.677 & 165.527 & 1469 \\
\hline & 2013 & 112.736 & 198.636 & 1762 \\
\hline & 2014 & 108.508 & 186.291 & 1717 \\
\hline & Ortalama & 105.905 & 179.770 & 1701,8 \\
\hline \multirow{6}{*}{ KİMYON } & 2010 & 171.242 & 12.587 & 74 \\
\hline & 2011 & 200.117 & 13.193 & 66 \\
\hline & 2012 & 226.294 & 13.900 & 61 \\
\hline & 2013 & 247.045 & 17.050 & 69 \\
\hline & 2014 & 224.421 & 15.570 & 69 \\
\hline & Ortalama & 213.824 & 14.460 & 67,8 \\
\hline \multirow{7}{*}{ ANASON } & 2010 & 186.450 & 13.992 & 75 \\
\hline & 2011 & 211.542 & 14.879 & 70 \\
\hline & 2012 & 194.430 & 11.023 & 57 \\
\hline & 2013 & 152.431 & 10.046 & 66 \\
\hline & 2014 & 140.506 & 9.309 & 66 \\
\hline & Ortalama & 177.072 & 11.850 & 66,8 \\
\hline & 2010 & 85.351 & 11.190 & 131 \\
\hline
\end{tabular}


Gökçe Z., Efe L.

\begin{tabular}{|c|c|c|c|c|}
\hline \multirow{4}{*}{ KEKİK } & 2011 & 77.707 & 10.953 & 141 \\
\hline & 2012 & 94.283 & 11.598 & 123 \\
\hline & 2013 & 89.137 & 13.658 & 153 \\
\hline & 2014 & 92.959 & 11.752 & 126 \\
\hline \multirow{4}{*}{ ÇEMEN } & 2010 & 1.651 & 200 & 121 \\
\hline & 2011 & 1.055 & 141 & 134 \\
\hline & 2014 & 1.979 & 218 & 110 \\
\hline & Ortalama & 1.402 & 164.2 & 117.2 \\
\hline
\end{tabular}

* Kaynak: [14]

Tablo 1. incelendiğinde çemen bitkisinin, ülkemizde ekim alanı ve üretim bakımından 5. sırada yer alan önemli bir baharat bitkisi olduğu görülmektedir.

Türkiye'de yıllara göre çemen üretimi Tablo 2.'de ve çemen ihracatı Tablo 3.'de verilmiştir.

Tablo 2. Türkiye'de yıllara göre çemen üretimi*

\begin{tabular}{|c|c|c|c|}
\hline Yıllar & Ekilen Alan(da) & Üretim (ton) & Verim (kg/da) \\
\hline $\mathbf{2 0 0 5}$ & 8000 & 760 & 85 \\
\hline $\mathbf{2 0 0 6}$ & 7430 & 36 & 66 \\
\hline $\mathbf{2 0 0 7}$ & 545 & 195 & 104 \\
\hline $\mathbf{2 0 0 8}$ & 1880 & 180 & 160 \\
\hline $\mathbf{2 0 0 9}$ & 1127 & 200 & 121 \\
\hline $\mathbf{2 0 1 0}$ & 1651 & 141 & 134 \\
\hline $\mathbf{2 0 1 1}$ & 1055 & 67 & 104 \\
\hline $\mathbf{2 0 1 2}$ & 645 & 195 & 116 \\
\hline $\mathbf{2 0 1 3}$ & 1678 & 218 & \\
\hline $\mathbf{2 0 1 4}$ & 1.979 & & \\
\hline
\end{tabular}

*Kaynak: [14]

Ülkemizdeki 2014 yılı verilerine göre çemen üretimine bakıldığında; üretim miktarı 218 ton, ekim alanı 1979 da ve verim ise $110 \mathrm{~kg} /$ da'dır. Çemen üretimi, 2013 yılında 195 ton iken, 2014 yılında 218 tona yükselmiştir. Yine çemen ekim alanı 2013 yılında 1678 da iken, 2014 yılında 1979 dekara yükselmiştir (Tablo 2).

Tablo 3.Türkiye'de yıllara göre çemen ihracatı*

\begin{tabular}{|c|c|c|}
\hline Yıllar & İhracat Miktarı (kg) & İhracat Değeri (\$) \\
\hline $\mathbf{2 0 1 0}$ & 27431 & 71792 \\
\hline $\mathbf{2 0 1 1}$ & 28828 & 96667 \\
\hline $\mathbf{2 0 1 2}$ & 38663 & 56945 \\
\hline $\mathbf{2 0 1 3}$ & 18846 & 91674 \\
\hline
\end{tabular}

*Kaynak: [15] 
Çemen tohumları ülkemizde baharat olarak kullanıldığı gibi ihracatı da yapılmaktadır [16]. Tablo 3. İncelendiğinde, çemen bitkisinin 2010 yılı ihraç miktarı $27.431 \mathrm{~kg}$, bu ihracatın değeri ise 57.727 \$, 2011 yılı ihraç miktarı $28.828 \mathrm{~kg}$, değeri ise 71.792 \$, 2012 yılı ihraç miktarı $38.663 \mathrm{~kg}$, değeri ise 96. 667 \$, 2013 yılı ihraç miktarı $18.846 \mathrm{~kg}$, değeri ise 56.945 \$, 2014 yılı ihraç miktarı $30.901 \mathrm{~kg}$, değeri ise 91.674 \$ şeklinde gerçekleşmiştir [15].

\subsection{Kullanım alanları}

Çemen bitkisinin birçok alanda kullanıldığı bilinmektedir. Bu bitkinin, özellikle tıp, gıda, eczacılık ve kozmetik gibi alanlarda yaygın kullanımı olmakla beraber, halk hekimliğinde de kullanımı mevcuttur. Çemen bitkisinin hem tohumları hem de vejetatif aksamı kullanılır.

Uluslararası ticarette tohumları, taze ve kuru yaprakları körilere tat ve lezzet vermek için kullanılmaktadır. Gıda sanayinde lezzet arttırıcı olarak, bakteriyel bulaşmayı önlemede ve raf ömrünü uzatmak amacıyla da kullanılmaktadır. Çemen tohumlarının öncelikli kullanım alanı işlenmiş et ürünleridir. Ayrıca Hindistan, İtalya ve bazı ülkelerde çemenin taze yaprakları sebze ve baharat olarak da tüketilmektedir. Güneydoğu Anadolu Bölgesi'nde hazırlanan yöresel bazı acı sosların bileşiminde de çemen tohumu mevcut olup, Hindistan' da kırsal kesimde tıbbi olarak ve salamura yapımında da kullanılmaktadır [17].

Çemen tohumları gıda sanayinde firın ve et ürünleri, alkollü içecekler, şekerlemeler, çeşni ürünleri, dondurma, şurup ve şekerli soslar ve jelatin, pudingler, çikletler ve şekerli kremalara da ilave edilmektedir. Tohumları kurutulup çerez olarak yenildiği gibi, ögütülmüş halde mutfakta baharat karışımlarında, turşularda, çorbalarda, salatalarda, güveçlerde, soslarda ve et üzerinde kullanılmaktadır [18]. Pastırma üzerine kaplanan karışımın da başlıca bileşenidir. Çemenin pastırma üzerine kaplanmasındaki amaç pastırmayı dış mikroorganizma etkilerinden korumaktadır [2, 19]. Türk Standartları Enstitüsü (TSE); çemen hamuru için \% 50 çemen (buy otu) tohumu unu, \% 35 sarımsak ve \% 15 kırmızı toz biber karışımını önermektedir. Çemenin bileşimine giren katkı maddelerinden çemen tohumu ununun yapıştırıcı özelliği olup kılıf görevi görerek pastırmaya lezzet ve aroma vermektedir [20].

Çemen bitkisinin meyve kabuğu, Poy adı verilen ve baharat olarak kullanılan bir toz haline getirilir [7, 21]. Bilhassa İnegöl ve Karacabey köylerinde elde edilmektedir. Açık sarı renkli, hafif kokulu ve lifli bir tozdur. İstanbul ve Bursa bölgelerinde baharat olarak kullanılır. Kullanılışı Bulgar göçmenleri tarafindan başlatılmış ve zamanla yaygınlaşmıştır [7].

Çemen farklı ekim nöbeti sistemlerinde toprak özelliklerinin iyileştirilmesinde ve yeşil gübre olarak kullanılabilmektedir. Gerek insan, gerekse hayvan beslenmesinde iyi bir protein kaynağıdır. Ayrıca çemen bir yıllık serin iklim baklagil yem bitkisidir [22]. Otu ve taneleri yem bitkisi olarak kısıtlı ölçülerde kullanılır [23].

Çemen tohumları sabit yağ, musilaj, fosforlu bileşikler, fitin, kolin, trigonelin, hidroliz sonucu diosgenin veren bir saponin, protein, uçucu yağ ve nikotin amid içerir. Halk arasında çemenden tahriş giderici, barsak yumuşatıc1, gaz giderici, sindirimi kolaylaştırıcı, süt artırıcı, göğüs yumuşatıcı, balgam söktürücü olarak yararlanılmaktadır. Bunun yanında bronşit, ateş düşürücü, boğaz ağrısını giderici, yara iyileştirici ve kan şekerini düşürücü özelliğinden dolayı şeker hastalığında ve kanser tedavisinde 
kullanılmakta, ayrıca bazı lokal bölgelerde çemen tohumlarından elde edilen boya kozmetik ürünlerinin boyanmasında ve afrodizyak olarak da kullanılmaktadır [2, 4, 7, 24, 25].

Çemenin depo zararlılarını uzaklaştırmada kullanıldığı da bildirilmektedir [26]. Depo şartlarında yapılan gözlemlerde, çemen tohumlarının özellikle farelere karşı repellent etkiye sahip olduğu gözlenmiştir [12].

Tohumunda önemli miktarda protein, mineral maddeler ve vitaminler bulunmaktadır. Çemen tohumunun bileşiminde; \% 27 protein, \% 8 sabit yağ, yağında \% 52 oleik asit ile \% 40 linoleik asit, uçucu yağ, azotlu bileşikler, fitin, kolin, rutin, nikotin amid, kumarin, kül (\% 3-4), flavonoid, müsilaj (\% 30), trigonellin (\% 1), eholine, sentionine ve cerpaine alkaloitleri ve yağlı embriyosunda hidroliz sonucu diosgenin (\% 0.8-2.2) veren steroidal saponinler (\% 5-7) ve Vitamin A, B ve C, kalsiyum, demir ve diğer mineraller bulunur. Çemen tohumunun tedavi edici özelliği, genellikle içerdiği steroidal saponinlerden kaynaklanır [2, 27, 28, 29, 30]. Tohumların embriyosunda bulunan diosgenin adı verilen saponozitin varlığının saptanması sonucu bitkinin Avrupa, Amerika ve Doğu Afrika'da kültürü yaygınlaşmaya başlanmıştır. Diosgenin, kortikosteroidlerin sentezinde yararlanılan değerli bir bileşiktir [31]. Tohumların en önemli aminoasitlerinden valin, fenilalanin, lisin, glisin, aspartik asit, glutamik asit, serin ve lösince zengin olduğu tespit edilmiştir [32]. Tohumun içerdiği saponin sebebiyle iştah açar, bronşiti ve boğaz ağrılarını hafifletir, rahatlama sağlar, balgam söktürür ve göğsü yumuşatır. Müsilaj sebebiyle yumuşatıcı özelliklere sahip olduğundan öksürük ilacı olarak kullanılabilir. Acı oluşu nedeniyle sindirim sistemini uyarır, sindirim işlemini kolaylaştırır. Diyarenin tedavisinde yararlıdır. Ayrıca bedeni güçlendirici bir tonik özelliğinde olup emzikli annelerde süt gelişini artırır. Karaciğer ve böbrek hastalıklarına, çarpıntıya, kan zehirlenmesine, ateşi düşürmeye, barsak ve mide tembelliğine, rahim iltihap ve akıntılarına, böbrek ve idrar yolları kum ve iltihabına, böbrek ve mesane taşlarını parçalamaya ve nefes darlığına iyi gelir [32].

Çemen yağı, bal mumu ile karıştırılırsa elde edilen merhem, soğuktan ileri gelen çatlaklara iyi gelir. Çemen yağı, mersin yaprağının suyu ile karıştırılıp saçlara sürülürse, saçları besler, parlatır ve dökülmesini önler. Çemen tohumlarının incir ile birlikte lapa haline getirilip vücuttaki şişlik üzerine konulduğunda şişliği yumuşattığı söylenmektedir [30]. Ayrıca Almanya' da çemen tohumları ezilerek merhem haline getirilir ve sivilcelere karsı pansuman olarak kullanılır [7, 33, 34, 35].

Çemen (Trigonella foenum-graecum L.) tohumundan elde edilen birçok preparatlar tedavi edici özelliği sayesinde kimyasal ilaçlardan daha çok tercih edilir duruma gelmiştir. Yurtdışında izin verilen ve içeriğinde Trigonella foenum-graecum L. bulunan preparatlar mevcuttur. Bu bitkiden üretilen başlıca preparatlar “Bifosept H, Grindelia Oligoplex, Kneipp Husten, Bronchial Tee N.”dir [36].

Günümüzde inek ve at gibi büyük baş hayvanların yara tedavisinde de kullanılmaktadır. Çemenin yeşil dal ve yaprakları bazı içkilerin ve sahte akçaağaç şurubunun yapımında kullanılmakta, genç bitkileri özellikle Hindistan’da yeşillik olarak değerlendirilmektedir [21].

Çemen tohumları ayrıca pamuk tohumları ile karıştırılarak hayvanlara yedirilip süte akıcılık kazandırılmasında kullanılırken, Kuzey Afrika'da ekmeklik buğdaya, İsviçre'de peynir ve turşulara katılarak kullanıldığ 1 bilinmektedir [37].

Halk hekimliğinde kuvvet verici, afrodizyak, solunum yolları rahatsızlıkları ve şeker hastalığında, yüksek kolestrolde, diabet hastalıklarında, pankreas fonksiyonlarının düzenlenmesinde, 
antitümör, antiviral, antimikrobiyal ve antioksidan özellikleriyle de tedavide; tohumları öğütüldükten sonra baharat ve baharat karışımlarında kullanılmaktadır. Çemen tohumu ve otu hayvan beslemede de kullanılmaktadır. Tohumları bünyesinde bulunan "cumarin" den dolayı sığır, at ve domuzların semirtilmesi için günde 25-30 gr un halinde diğer yemlere ilave edilir. Çemenin otunda protein miktarı \% 21 'e kadar çıkmaktadır. Çemen aynı zamanda tekstil endüstrisinde de kullanılır. Özellikle ketenden imal edilen kumaşlara "apre" (dokumacılıkta, boyacılıkta cila olarak kullanılan madde) vermek amacıyla kullanılmaktadır. Çemenin bu amaçla kullanılması, tohumunda \% 20-40 civarında bulunan müsilajlı maddelerden kaynaklanmaktadır [3, 7, 38, 39].

\section{Sonuç}

Tüm dünyada önemi gün geçtikçe artan tıbbi ve aromatik bitkiler ülkemiz için de önem kazanmaktadır. Türkiye, tıbbi ve aromatik bitkiler üretimi bakımından, iklim ve zengin bitki çeşitliliği bulundurması nedeniyle önemli bir potansiyele sahiptir.

Çemen bitkisi birçok kullanım alanına sahip ve ülkemiz ekolojisinde kolaylıkla yetiştirilebilecek bir bitki olmasına rağmen, ülkemizde üretimi ve ihracatı istenilen seviyelere ulaşamamıştır. Üretimin ve buna bağlı olarak da çemen ihracatının artırılması için, bu bitkinin tanıtımına önem verilmeli, kullanım alanları genişletilmeli ve halkımızın tüketim alışkanlıkları içinde daha fazla yer edinmesi sağlanmalıdır. Çemen bitkisinden elde edilen ürünlerin standartlarının iyileştirilmesi ve en iyi yetiştirme koşullarının saptanması da bu bitkinin önemini giderek artıracaktır.

$\mathrm{Bu}$ derlemenin hazırlanmasında tıbbi ve aromatik bitkiler içerisinde önemli bir yere sahip olan çemen bitkisinin öneminin vurgulanması ve çemen bitkisi hakkında ileride yapılacak olan çalışmalarda yararlanılması için bilgiler sunmak amaçlanmıştır.

\section{Kaynaklar}

[1] Beyzi, E., "Çemen (Trigonella foenum-graecum L.)'de Farklı Fosfor Dozlarının Verim ve Bazı Morfolojik Özellikler Üzerine Etkileri” Ankara Üniversitesi, Fen Bilimleri Enstitüsü, Yüksek Lisans tezi, 43 s, Ankara, 2011

[2] Akgül, A., "Baharat Bilimi ve Teknolojisi” Gıda Teknolojisi Derneği Yayın No: 15, 451 s, Ankara, 1993

[3] Gençkan, M. S., "Yem Bitkileri Tarımı" Ege Üniversitesi Ziraat Fakültesi Yayınları No: 467, İzmir, 1983

[4] Arslan, N., Tekeli, S., Gençtan, T., "Değişik yörelere ait çemen (Trigonella foenum-graecum L.) populasyonlarının tohum verimleri" VIII. Bitkisel İlaç Hammaddeleri Toplantısı 19-21 Mayıs, Cilt II: 93-97, İstanbul, 1989

[5] Davis, P.H., "Flora of Turkey an the east aegean islands” Edinburg University, 3: 465-482, 1982.

[6] Köroğlu, H.A., "Çemen bitkisinde fenolojik, morfolojik ve teknolojik özellikleri üzerine araştırmalar” Ankara Üniversitesi, Fen Bilimleri Enstitüsü, Yüksek lisans tezi, 83 s, Ankara, 1985

[7] Baytop, T., “Türkiye’de Bitkiler İle Tedavi” İstanbul Üniversitesi Eczacılık Fakültesi Yayınları No: 3255, İstanbul, 1984 
[8] Anonim, “Trigonella foenum-graecum”.http://www.doktordoga.com/default. (Erişim tarihi: 03.01.2015).

[9] Özdemir, B., "Seçilmiş bazı çemen (Trigonella foenum-graecum L.) hatlarının verim ve verim öğeleri üzerinde araştırmalar” Ankara Üniversitesi, Fen Bilimleri Enstitüsü, Yüksek Lisans tezi, 60 s, Ankara, 1999

[10] Özgüven, M., Sekin, S., Gürbüz, B., Şekeroğlu, N., Ayanoğlu, F. , Ekren, S., “Tütün, tıbbi ve aromatik bitkiler üretimi ve ticareti”. VI. Teknik Tarım Kongresi Bildiri Kitabı 3-7 Ocak, Cilt.1: 481-501, Ankara, 2005

[11] Kevseroğlu, K., Özyazıcı, G.. Azotlu gübre dozlarının çemen (Trigonella foenum graecum L.) bitkisinin bazı tarımsal özelliklerine etkileri. Türkiye II. Tarla Bitkileri Kongresi Bildiri Kitabı 22-25 Eylül, Samsun, 367-371, 1997

[12] Kizıl, S., Arslan, N., "Investigation of the effects on yield and yield components of different sowing rates in some fenugreek (Trigonella foenum-graecum L.) lines”. Journal of Agricultural Sciences, 9(4), 2003

[13] Tunçtürk, M., Çelen, A.E., "The effect of different seeding rates on the yield and some yield characteristics of fenugreek (Trigonella foenum-graecum L.)”. Turkish Journal of Field Crops, 10 (1): 37-42, 2005

[14] Anonim, “Türkiye İstatistik Kurumu Web Sayfası”. www.tuik.gov.tr. (Erişim tarihi: Temmuz2015)

[15] Anonim, “Türkiye İstatistik Kurumu Web Sayfası”. www.tuik.gov.tr. (Erişim tarihi: Haziran2015)

[16] Gürbüz, B., Arslan, N., Gümüşçü, A., “The correlation and path analysis of yield components on selected fenugreek (Trigonella foenum-graecum L.) lines”. Journal of Agricultural Sciences, 6, 1, 7-10, 2000

[17] Gupta, K., Thakral, K. K., Arora, S. K., Chowdhary, M. L., "Structural carbohydrate and mineral contents of fenugreek seeds Indian Cocoa”. Arecanut and Spices Journal, 20, 4, 120-124, 1996

[18] Koç, H., “Bitkilerle Sağlıklı Yaşama”. Kültür Eserleri Dizisi, Yayın No:2883, 2002

[19] Küçük, M., Gürbüz, B., "Bazı çemen (Trigonella foenum-graecum L.) hatlarında yağ ve yağ asitleri bileşenlerinin araştırılması”. Gıda Dergisi, 24, 2, 99-101, 1999

[20] Kök, F., "Pastırma Üretim Teknolojisini Geliştirme Çabaları”. Uludă̆ University Journal of Faculty Veteranary Medicine, 22, 1-2-3, 109-114, 2003

[21] Er, C., Yıldız, M., “Tütün, ilaç ve baharat bitkileri”. Ankara Üniversitesi Tarla Bitkileri Bölümü, II. Baskı, 1997

[22] Manga, İ., Acar, Z., Ayan, İ., “Baklagil Yem Bitkileri”. Ondokuz Mayls Üniversitesi Ziraat Fakültesi Yayınları Ders Notu: 274, Samsun, 1995

[23] Açıkgöz, E., “Yem Bitkileri”. Uludağ Üniversitesi, Ziraat Fakültesi, Tarla Bitkileri Bölümü, 3. Bask1, 2001

[24] Hornok, L., "The Cultivation of Medicinal Plants. Cultivation and Processing of Medicinal Plants (Ed. L. Hornok)”. pp. 289-290, Budapest, 1992 
[25] Abdelgani, M.E., Elsheikh, E.A.E., Mukhtar, N.O., "The effect of rhizobium inoculation and chemical fertilization on seed quality of fenugreek”. Food Chemistry, 64, 289-293, 1998

[26] Duke, A. J., "Handbook of Legumes of World Economic Importance”. Plenum Press, 106-110, Newyork 1981

[27] Mebey, R., McIntyre, M., Michael, P., Duff, G., Stevens, J., “The news age herbalist”. Collier Booly, 93-98, Newyork, 1988

[28] Shirani, G., Ganesheranee, R., "Exruded product with fenugreek (Trigonella foenum-graecum L.) chickpea and rices: Physical properties sensory acceptability and glycaemic index". Journal of Food Engineering, 90, 44-52, 2009

[29] Acharya, S.N., Thomas, J.E., Basu, S.K., "Fenugreek, an alternative crop for semiarid regions of North America”. Crop Science, 48, 3, 841-853, 2008

[30] Anonim, “Çemen (Trigonella foenum-graecum L.)". http://www.agaclar.net. (Erişim tarihi: 09.01.2015)

[31] Tanker, N., Koyuncu, M., Coşkun, M., "Farmasötik Botanik”. Ankara Üniversitesi Eczacıllk Fakültesi Yayınları, Ders Kitapları No:78, 394 s., Ankara, 1998

[32] Nour, A.A.M., Magboul, B.I., "Chemical and Amino Acid Composition of Fenugreek Seeds Grown in Sudan”. Food Chemistry, 22, 1-5, 1986

[33] Acharya, S.N., Basu, S.K., Thomas, J.E., "Medicinal properties of fenugreek (Trigonella foenum-graecum L.) : A review of the evidence based information”. Advances in medicinal plant research. 81-122, 2007

[34] Asımgil, A., "Şifalı Bitkiler Kitabı”. Timas Yayınları No: 176, 75-76 s., İstanbul, 1997

[35] Basch, E., Ulbricht, C., Kuo, G., Szapary, P., Smith, M., "Therapeutic applications of fenugreek". Alternative Medine Review, 8, 1, 20-27, 2003

[36] Schönfelder, I., “Der neue Kosmos-Heilpflanzenführer”. Kosmos, Stuttgart, 2001

[37] Soylu, S., Sade, B., Atalay, E., Pilgir, Ç., Çetinkaya, Ü., “Çemen (Trigonella foenum graecum L.) genotiplerinde farklı ekim zamanlarının verim ve verim öğeleri üzerine etkileri”. Selçuk Üniversitesi Ziraat Fakültesi Dergisi, 14, 22, 131-142, 2000

[38] Fazli, F.R.Y., Hardman, R., "The spice, fenugreek (Trigonella Foenum graecum L.): its commercial varieties of seed as a source of diosgenin”. Tropical Science, 10, 66-78, 1968

[39] Smith, A., "Selected Markets for Turmeric, Coriander, Cumin and Fenugreek seed and Curry Powder”, Tropical Product Institute, Publication No. G 165, London, 1982 